\title{
Improving the Competence of Pasraman Widya Dharma Management Through Website Training
}

\author{
I Dewa Alit Dwija Putra ${ }^{1 *}$ \\ ${ }^{1}$ Study Program of Visual Communication Design, Faculty of Creative Industry \\ Telkom University, Bandung, Indonesia \\ dwijaputra@telkomuniversity.ac.id \\ I Gusti Agung Rangga Lawe², Ganjar Gumilar ${ }^{3}$ \\ ${ }^{2,3}$ Study Program of Visual Communication Design, Faculty of Creative Industry \\ Telkom University, Bandung, Indonesia \\ agunglawe@telkomuniversity.ac.id, ganjargumilar@telkomuniversity.ac.id
}

(Received May 17, 2021, accepted July 22, 2021)

\begin{abstract}
Professional competency improvement for management at Pasraman Widya Dharma in Bandung is very important in this era of globalization. There is a need for partnership with a higher education institution to run an empowerment program in a form of training in using internet website. Website is an easily accessible information media which is suitable to publish information in informal education institutions such as Pasraman. The empowerment is intended to improve the professional competence of staffs and administrators who provide services at institutional facilities within the Bandung Hindu community. The empowerment was implemented using Service Learning method in order to optimize the potential of the community partnership with a focus on training and assistance related to improving the professional competency of the administrators and managers of the Widya Dharma Pasraman Bandung. The professional competency of the managers was observed to be improved significantly based on the result of the training program. This leads to a conclusion that the program is potential to be carried out in continual basis.
\end{abstract}

Keywords: manager; pasraman; website training 


\section{Introduction}

The innovation activities conducted through the Telkom University community service program at Pasraman Widya Dharma in Bandung are not new but have the ability to provide changes for both the individuals and the group. The concept of innovation, however, etymologically originates from the Latin word "innovaation" which means renewal and change while the verb "innovo" means updating and changing. This means innovation is a new change implemented to repair through planning and not by chance (Rusdiana, 2014). This, therefore, shows the community service activities in Pastraman are planned and implemented to increase the competence of the manager, staff, and other human resources of the institution. The conventional method of mentoring through manuals was replaced with a more practical and efficient approach to managing innovation in the form of digitalization. Moreover, the new knowledge was observed to be more on the staff with interest in communication and information technology (ICT).

Community service is one of the Tri Dharma required to be conducted by lecturers. This is indicated in the devotion integrated into Phase I of 2021 which requires the lecturers to collaborate with the apprentices or professional work students to explore their abilities through the assistance provided by the community-Telkom University partnership program. The students assist the lecturers as a companion mentor while the knowledge they acquire in the college was tested against societal norms due to the several roles they are expected to play in the community. The involvement of students in the program is also an alternative to direct work due to the difficulties of having appropriate employment as a result of COVID-19 which led several industries to bankruptcy both in Indonesia and the world in general. It is, therefore, important to compile a joint activity program based on the problems discovered from field surveys.

Phase I of the Telkom University community service was initiated in 2021 in collaboration with a Hindu religious social education institution known as Pasraman. The observations and interviews conducted with the chairman of Pasraman and several managers showed the inappropriate use of ICT technology-based media to pass information across to users including the students, teachers, and parents. The administrators and staff were observed to be using conventional and manual methods and this means many of the activities and programs of the institution are not known to these users. This shows there is a problem of professionalism and 
limitation among the managers and this means the services provided for the public need to be enhanced further to ensure a mutual step in achieving the desired goals of religious education. Therefore, the Telkom University community service team initiated a mentoring program for the Pasraman managers on managing information through websites in order to improve their ability to create media and interesting content as well as accessible information.

Information technology has been advancing rapidly in this era of globalization and this has made information easily accessed anytime and anywhere as long as there are internet facilities. An example of the systems operationalized through internet media is a website which is indirectly opened when people access the internet on a desktop device or mobile smartphone to open their desired pages. The website is, therefore, defined as a collection of pages which displays different kinds of text information, data, silent and moving images, animated data, sounds, videos, or a combination of all, both static and dynamic, to form a series of interrelated systems which are connected to a page network or hyperlink (Lestari et al., 2020).

The website has been generally used in corporate promotion and agencies as well as to promote goods and services in addition to its ability to provide media information. It also has the ability to increase corporate and brand image with several websites observed to have sprung up for business interests or to deliver certain information in recent times. Moreover, most of them are also applied in the process of transactions and data and they can also be used in the education sector to promote information to the users or consumers.

Websites and content-making methods are needed in the Pasraman environment as indicated by the lack of appropriate information media with several parents and users discovered to be complaining about the limited information available as regards the institution. This millennial era, however, requires technology-based information media are developed to meet up with this present generation classified as a native digital generation based on their level of comfortability with the use of digital equipment (Amin, 2019). This means the administrators and managers in the institution need the appropriate facilities and training on digital-based information technology in order to provide good service to their millennial students.

Pasraman is a school that teaches Hinduism and also anticipates several problems faced by people outside Bali. This is considered important due to the fact that formal elementary, 
middle, and high school students often do not have religious education because of the limited teaching staff and facilities.

Pasraman boarding schools providing religious education were legalized through the Government Regulation (PP) Number 55 of 2007 concerning Religions and Religious Education in Article 41 which states that religious education can be conducted using informal methods to complement incomplete formal religious education including Hinduism in formal schools in order to increase the Sraddha and Bhakti Hindu (Karmini, 2018).

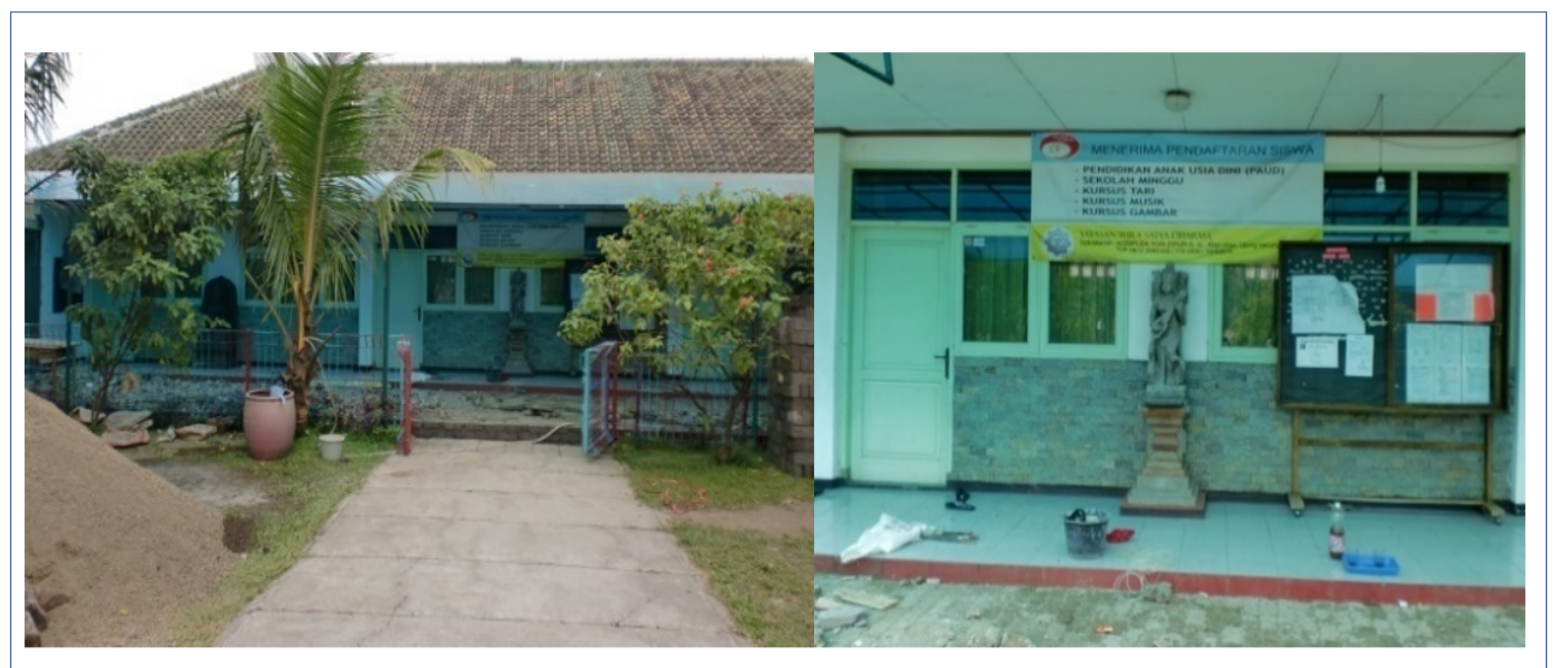

Source: private collection

Fig. 1. Pasraman Widya Dharma school building in Ujung Berung Bandung

Pasraman is, therefore, a social institution with administrators and several educators with background discovered not to be in line with the competencies. The managers focus on relaxation (ngayah) to ensure sustainability in receiving religious education while their technology literacy and information are also limited due to the fact that all management activities are usually conducted conventionally.

The Telkom University Community service team discovered the main problem is the lack of ICT knowledge by managers and teachers and this leads to difficulties in passing information and communicating especially during the COVID 19 period when all activities were required to be conducted online from home. Most parents are confused when finding information related to teaching activities and programs in Pasraman during this period and this led to the Telkom community service team to collaborate with the manager to provide website training for the administrators and staff. 
During the pandemic, the problems faced by Pasraman administrators were the difficulty of communicating and conveying information related to the teaching and learning process, such as; new student data collection, financial administration, teaching methods, and class schedules. Likewise, student extracurricular activities such as competitions at the regional and national levels are difficult to convey. Communication and information media is only done through Smartphones with the WhatsApp platform.

A study by I Ketut Angga Irawan which focuses on character education in several Pasraman in Jabodetabek outside of Bali was unable to provide the expected target. The learning process was found to be limited by infrastructures as well as limited managers and teachers (Irawan, 2013). The average management staff was observed to be parents without competence in their fields let alone information technology while administrative records and documentation are also conducted manually.

The managers in Hinduism boarding schools plan, implement, and evaluate education programs and also determine the policy to be implemented to ensure the education process is run according to the vision and mission of the institution. These responsibilities showed they need to improve their professionalism and insight in managing Pasramans. This, therefore, led the community service team from Telkom University to collaborate with other parties to provide a mentoring program for the managers or partners to change and transmit the changes to other communities.

The empowerment was conducted to increase the competence of the professional management of Pasraman Widya Dharma located at Ujung Berung, precisely on H.A. Nasution Street, No. 9 TNI complex Bandung, West Java. The process was implemented using "Service Learning" which is one of the approaches in teaching that combines academic goals with the efforts to foster awareness towards solving the community issues directly. This means the students are also included in providing service to the community without specifically teaching a particular course (Setyowati \& Permata, 2018). 


\section{Methods}

So that community service programs can run well and are directed. Therefore the "Service Learning" method is used, which involves more collaboration and togetherness in achieving goals. The "Service Learning" method was used to implement the empowerment to ensure the students play an active role in providing the training while the lecturer only served as a material provider through lectures and supervision of the activity. This is one of the experimental learning methods which is based on applying what is studied in the classroom to real activities in the community. This means the students are allowed to implement the theories they have studied and also render certain services to the community. The uniqueness of this method is the integration between the learning process with practical experience in the community as well as the reflection process (Wardhani, 2020).

Service Learning has several components such as academic material, relevant community service, and critical reflection and their relationship characterize this model. It is also a collaborative learning strategy which requires cooperation between universities and communities to promote academic enhancements, personal development, and involvement of the students in society.

Service Learning is one of the forms of implementing Experiential Learning which shows learning actually occurs when students participate in internships to actively construct meaning through guided real experience which allows them to develop critical thinking competencies based on reflection and, at the same time, contribute to the community (Amin 2019).

The problems of the partner including website training and content development were mapped before the empowerment was implemented. The whole process was conducted through several stages which include observation and discussion, interviews, planning, implementation, and evaluation or reflection.

The field observation or survey was initiated by visiting and communicating with Pasraman management, especially the principal and related parties such as the Chairperson of Banjar, Chair of the Foundation, Pura Management, and founder of Pasraman. The purpose and objectives of the community service program were explained and the meeting was held to identify the urgent needs and appropriate solutions to build a common awareness to achieve the desired goals. 
The next step was an interview conducted with the Principal Party to obtain more valid data on the problems in managing Pasraman with the focus on the capacity of the administrative staff expected to be the admin of the websites to be designed as well as interested teachers. The training material, technical guidance and assistance, and training time were also discussed.

This was followed by the preparation of an action plan based on the analysis of all necessary needs. This involved the compilation of simple modules of website learning models to be easily understood by the participants as well as the work stages and training schedules to ensure they do not interfere with the main activities of the participants which are mostly parents. The planning process was initiated with the main problem faced by the Pasraman managers and the solution provided is expected to provide collective awareness of the things to be addressed to ensure a conducive atmosphere for education activities.

The implementation stage focused on applying the action plans or programs designed during the planning stages with the first consideration being an effective and efficient time. Therefore, the program was held every Saturday and Sunday morning from 10:00 am to $12.00 \mathrm{pm}$ from the first to the third week of April 2021. The activities of students studying in the institution every week were also considered and the training was online with the dedication team consisting of two lecturers assisting the participants in practicing the design and management of websites.

The last stage is the program evaluation which was conducted every time an action is completed or currently being implemented to determine the success rate in line with the desired expectations and also to obtain feedback which was further used as references, notes, and thoughts in the framework used in preparing the stabilization and socialization programs for the related parties. 
These stages are, therefore, presented in Figure 2 as follows:

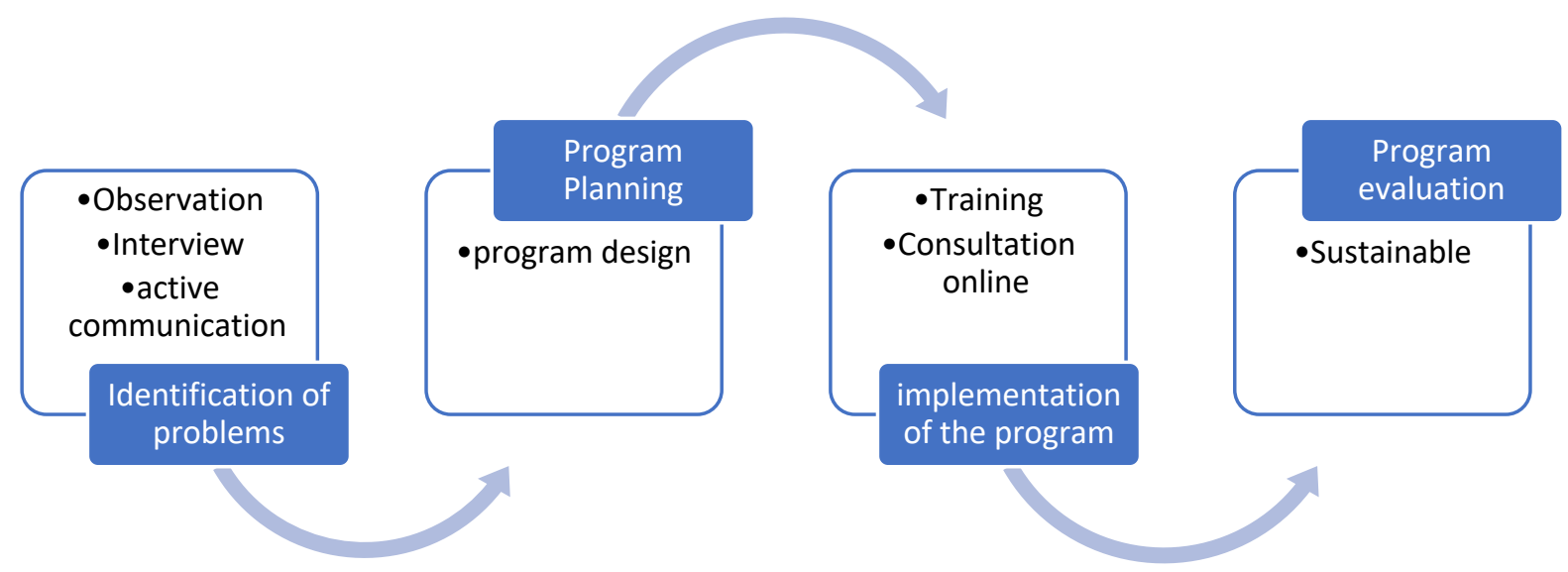

Fig. 2. Stages of program implementation

\section{Results and Discussion}

\section{Results}

Hinduism boarding schools are one of the containers used by the people to practically understand the teachings of Hinduism, especially the younger generation. They integrate the values of the teachings obtained in formal education institutions such as schools with nonformal institutions. Therefore the implementation of religious education in Pasraman focuses more on the affective and psychomotor aspects in order to directly implement the benefits in the daily real life of the students (Subagia, 2016).

There are, however, differences between the Pasraman in Bali and those outside the town. This is due to the fact that the Hinduism boarding schools in Bali have a learning system similar to Islamic boarding schools in Indonesia where students are required to live in a dormitory during the period of acquiring the education. Meanwhile, those outside Bali only operate at a specified time which is usually outside school hours such as Saturday or Sunday with a duration of 2 to 3 hours of meetings.

Pasraman Widya Dharma Ujung Berung was established in the 1990s based on public awareness of the importance of Hindu education and coaching. Elementary, middle, and high school students had to find a place to study this religion in several schools of Bandung at the beginning and this is evident in the use of SD Terang, Gatot Subroto ST by elementary and junior high students and SMAN 1 on Juanda ST. Dago, Bandung for those in high school. 
Religious schools used to be held every Sunday to avoid clashes with the regular or formal schools and the teachers were very limited with most of them brought in from the spiritual part of the TNI and government employees from the West Java Religion Office. The Pura Wira Satya Dharma Ujung Berung was, however, established in 1995 in the TNI Bandung Complex and all the activities of the education and development of Hinduism managed by Pasraman were transferred to the temple area.

The continuous development of this school led to a partnership to compile the activities needed to support its objectives and these include website training as well as content creation and management to improve religious education activities in the digital era. One of the training materials focuses on the basics of websites which include the domain, hosting, and content as well as different types of websites such as search engine, web portal, social networking or social media, forums, news portal and information, online store, blog, company profile, and others (Lestari et al., 2020). This material was provided to ensure the partners develop and adjust the website to the needs of the institution.

The next activity was determining the time to conduct the event based on the agreement of both parties. The training activities were held online through the Google Meet Flatform due to the prevalence of COVID-19 and the dedication team provided materials in line with the situation of the institution. Students, as partners, also assist the mentors in preparing a simple guidebook which provides easy instructions and tutorial on website design. This means the training process was initiated through the lectures provided by lecturers and the practical implementation was continued through the assistance provided in designing the websites.

The website training was held every Saturday and Sunday for two hours during the first and second week of April 2021. The community service team usually sends a simple guidebook to the partners to read to ensure the content is understood before the online meetings. The first training target was the administrative staff of the boarding schools such as the Secretary, Treasurer, Library, and Logistic officers after which they are expected to transfer the knowledge to interested friends, teachers, students, and communities. 


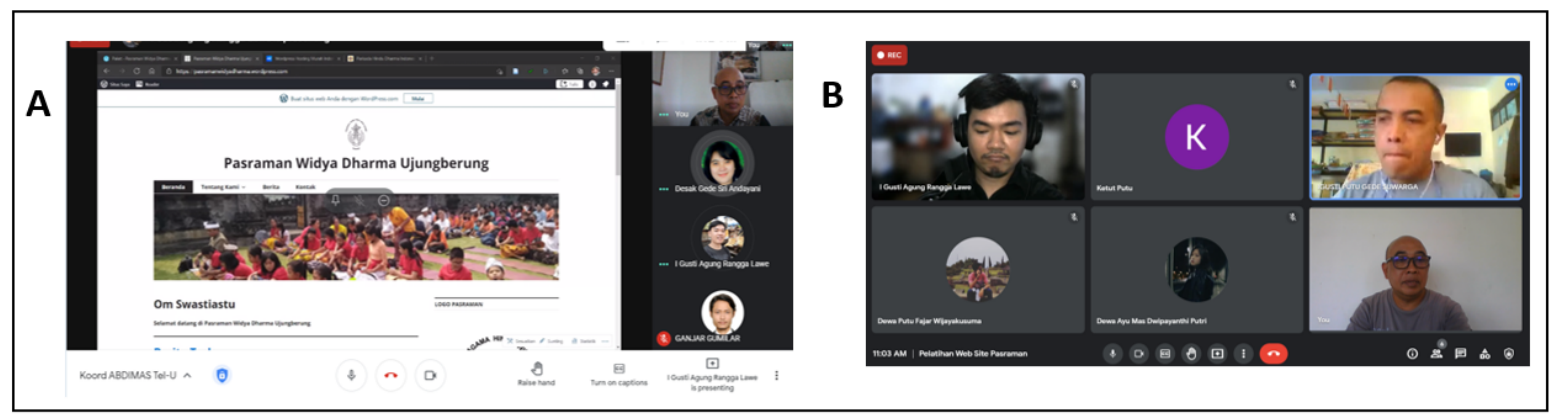

Fig. 3. (A) Coordination with Pasraman leaders to determine website design (B) Part of the program training participants

The participants practiced the design of a simple website using Content Management System (CMS) software because it is easy to understand for the Pasraman management staff considered to have limitations with information on technology. The software allowed them to build the website and fill content easily without adding program codes and the participants produced CMS-based websites using unpaid software such as wordpress.com which is a blog type of website commonly called blog hosting services. This provides the participants the ability to later create a blog website which generally has similar features with blog software (Zaki, Ali dan Community, 2009). Moreover, the CMS does not require an understanding of programming languages to create a website and also takes a short time.

WordPress is based on open-source and this means it is available to be used by anyone for any need. It is always updated from time to time to improve its weaknesses and disadvantages such as the security or features like every other software. There are, however, two types of WordPress and these include WordPress dot COM and WordPress dot org (Rahman, 2019) and the dot.com was used in the training and workshops. They both have simple features and are free, thereby, making the operational costs of maintaining websites to be much cheaper and practical.

The training and workshops held in Pasraman Widya Dharma also assisted the administrative staff in developing the technical skills to manage and operating the website apart from the knowledge on its design. The websites of the institution were designed to ensure information such as electronic brochures are accessible from all over the world for 24 hours and a search box is also provided to make it easier for visitors to find specific information on the web page. The design, therefore, prioritizes the information relating to religious education activities being conducted by the institution. 


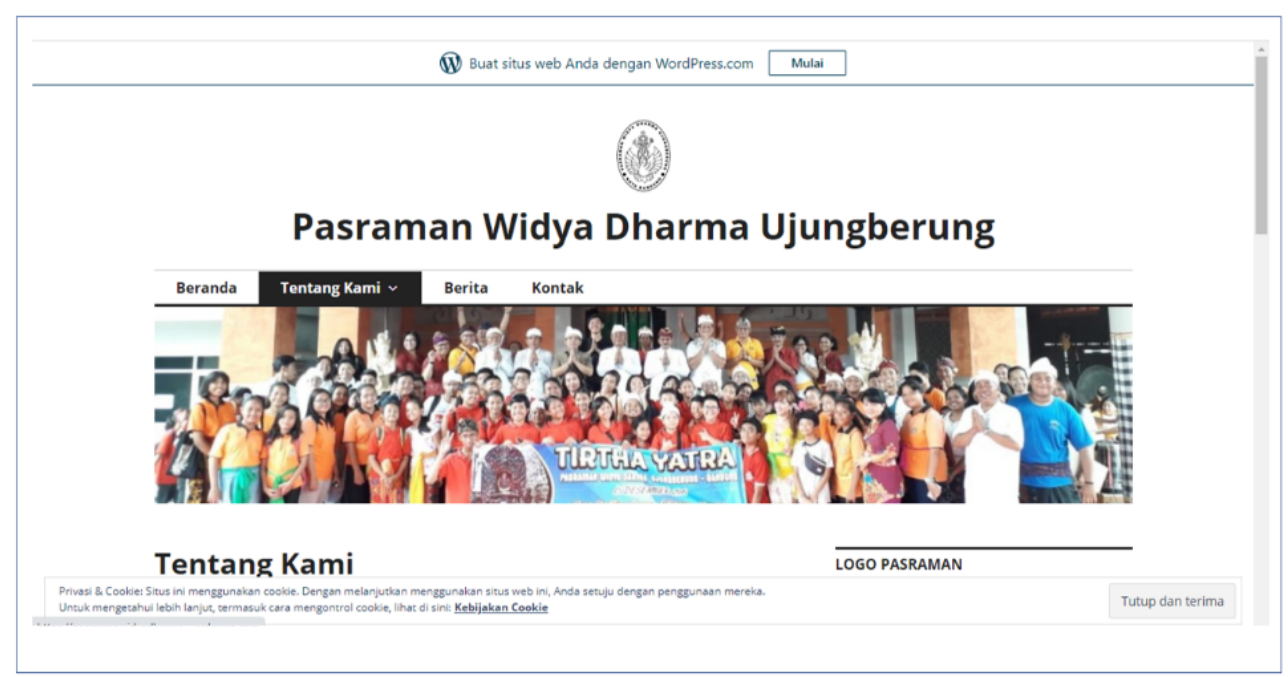

Fig. 4. The results of the Pasraman website design that have been published and can be searched via Google

\section{Discussions}

Telkom University community service team collaborated with some partners to provide training as an effort to build awareness on the importance of information technology for public services and the sustainability of Hinduism education in the Pasraman environment. This led to the provision of stable coaching to "help" the community with resources, opportunities, expertise, and knowledge required to improve capacity for future use of the residents (Nasdian, 2015). Therefore, the workshop participants acquired the knowledge and skills required to increase their competencies as Pasraman managers through web design and management training which is required to be gradually and independently integrated into the institutional system. This is further expected to advance the educational institution in the area.

The website training activities were held as an innovation which is "new" and a "change" to how things are previously being conducted in a deliberate effort to improve the ability to achieve certain goals in the management of educational institutions. The newness is associated with the implementation of strategies and methods previously not known to a certain set of people even though it is not new to others. (Rusdiana, 2014). Website is actually not a new concept for several people but it is for the administrators of Pasraman which are generally old. Meanwhile, the "change" is the transformation from the conventional use of technology to the digitization process through websites. 
The success rate or sustainability of the program was determined through the rapid or slow understanding of the partners to implement the knowledge acquired independently towards solving the related problems. The empowerment was supported by good cooperation between the Pasraman community and the Telkom University service team based on the due to social mapping such as observation and visitation of the target location before the program was implemented. The field survey was also used to identify the areas which needed to be strengthened in the community.

The mentoring model implemented in the boarding schools is in the form of direct interactions among partners to transfer the knowledge obtained from lectures, experiences, and meanings to the internship students. It was, however, challenging to communicate with the partners due to the difference in their level of understanding and this led to the delivery of material using other methods apart from the predetermined schedule such as through online consultation in WhatsApp Group for the participants to ask questions on the things they have forgotten. Moreover, several devices were used to deliver the materials due to the prevalence of COVID and the most significant obstacle to the online learning platform is the instability of the internet connection. This also led to the creation of an online consultation room through several media devices.

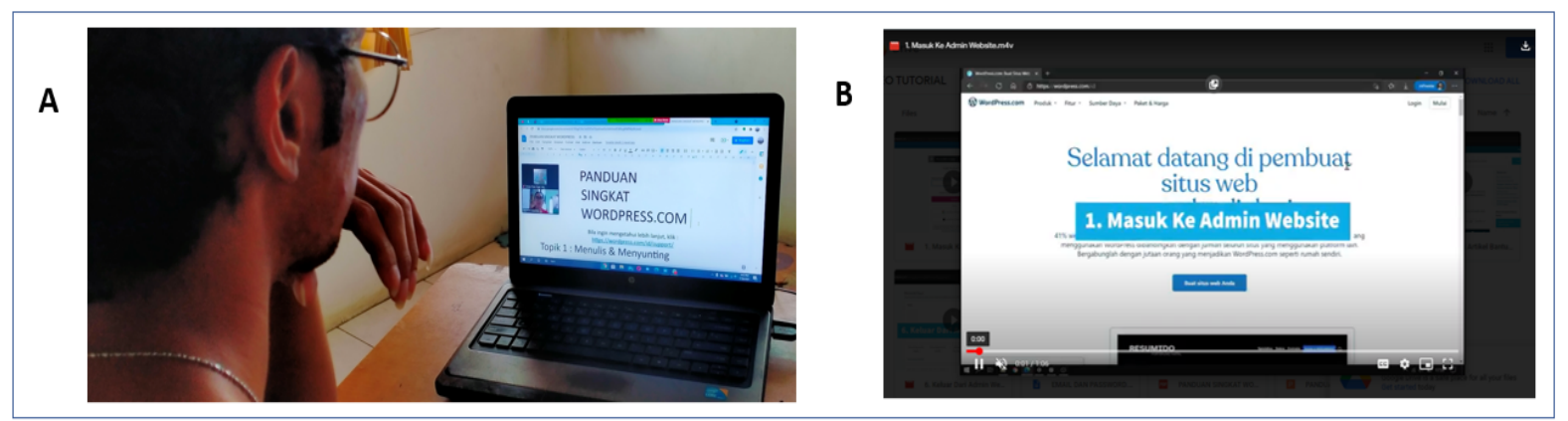

Fig. 5. (A) Internship students to provide personal training outside the program schedule (B) Training participants are also given video tutorials for independent study

The community service program was general conducted to change the individual behavior of managers in service and public facilities of educational institutions in order to improve the value of non-formal educational institutions in the community. It was also intended to assist individuals to have the capacity to conduct activities independently or in groups towards achieving expected competencies. 
Telkom's community service team requires questionnaires to provide the best service to partners and determine community service activities' continuity. The program participants were given a kind of questionnaire to provide input about the level of satisfaction in the implementation of this community service. Most of the participants filled out the "very satisfied" option with the following details; of the nine participants who were given a questionnaire, three people chose "satisfied", the remaining six people chose "very satisfied". In addition, the team also wanted to find out more about the shortcomings of lecturers and accompanying students in delivering material or providing services so that later they can be improved in the next program.

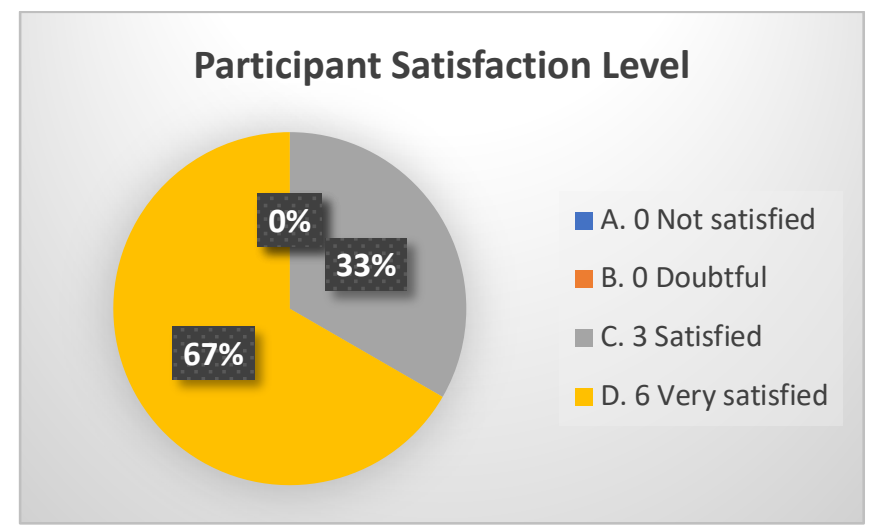

Fig. 6. Diagram of participant satisfaction level

The sustainable community service program aims to increase the competence of boarding schools by helping the teachers improve their skills in the use of digital learning media after the website training in order to enhance the learning process during COVID-19. Moreover, the focus is also to produce interesting teaching media with filmed software provided using existing information technology tool services which are to be implemented through the PKM regular Phase II program in 2021.

\section{Conclusion}

The community service program was implemented to empower the community using a Service Learning approach which pays attention to the potential of partners and is discovered to be very effective and efficient in solving problems. The full, serious, and earnest involvement of the community in the empowerment activities was discovered to have the ability to determine its successful implementation. Meanwhile, the community service team is also expected to target Pasraman outside Bandung. 


\section{Acknowledgements}

The DKV-Telkom University community service team, want to speak thank you very much to: Chairperson of Paspraman Widya Dharma Ujung Berung, to the Chairman of Banjar Bandung Timur, Chairman of the Wira Satya Dharma Foundation, the Telkom University Community and Research Institute for its activities, then to two students who helped this activity likewise to participants who have participated in the success of this training program.

\section{References}

Amin, S. (2019). Peningkatan Profesionalisme Guru melalui Pelatihan Pengembangan Media Pembelajaran Sparkol Videoscribe di Kabupaten Malang. Jurnal Pengabdian Pada Masyarakat, 4(4), 563-572. https://doi.org/10.30653/002.201944.238

Irawan, I. K. A. (2013). Analisis Implementasi Integrasi Pendidikan Dalam Pendidikan Agama Hindu di Pasraman se-Jabotabek. Jurnal Pasupati Vol. 2 No. 2. Juli-Des 2013, 2(2), 109115.

Karmini, N. W. (2018). Membangun Karakter Generasi Penerus Melalui Pasraman. Dharmasmrti: Jurnal Ilmu Agama Dan Kebudayaan, 9(2), 94-100.

Lestari, U., Triyono, J., \& Fatkhiyah, E. (2020). Bimbingan Teknis Pengembangan Web Di SMKN 2 Magelang Guna Mendukung Media Informasi Kegiatan Sekolah. Jurnal PkM Pemberdayaan Masyarakat, $\quad 109-120$. http://jurnalpkmpemberdayaan.com/index.php/PkMLP3K/article/view/12

Nasdian, F. T. (2015). Pemberdayaan Masyarakat (2nd ed.). Yayasan Pustaka Obor Indonesia. https://doi.org/769.32.6.2015

Rahman, S. (2019). Buku Pintar Web Desain dan SEO WordPress 5 PLUS. In PT Elex Media Komputindo (Vol. 1, Issue 1).

Rusdiana. (2014). Konsep inovasi pendidikan (Cetakan 1). CV. Pustaka Setia.

Setyowati, E., \& Permata, A. (2018). Service Learning: Mengintegrasikan Tujuan Akademik Dan Pendidikan Karakter Peserta Didik Melalui Pengabdian Kepada Masyarakat. Bakti Budaya, 1(2), 143. https://doi.org/10.22146/bb.41076

Subagia, I. N. (2016). Keberadaan Pasraman sebagai Penguatan Budaya Lokal Dikaitkan Dengan Peraturan Pemerintah No 55 Tahun 2007. Vidya Samhita Jurnal Penelitian Agama, II(2), 44-68. 
Wardhani, M. kusuma. (2020). SERVICE LEARNING MAHASISWA GURU SEBAGAI BENTUK PENGABDIAN KEPADA MASYARAKAT di YAYASAN SOSIAL EDUKATIF TANGERANG. Prosiding Konferensi Nasional Pengabdian Kepada Masyarakat Dan Corporate Social Responsibility (PKM-CSR), 3, 672-679. https://doi.org/10.37695/pkmcsr.v3i0.754

Zaki, Ali dan Community, S. (2009). Kiat Jitu Membuat Website Tanpa Modal (1st ed.). PT Elex Media Komputindo. 